\title{
Simulation and Dramatization Teaching Methods and Students' Academic Performance in English Language.
}

\author{
Uguma, Vincent Ugah \& Obiekezie, Eucharia Obiageli \\ Department of Arts Education \\ University of Calabar \\ Calabar, Nigeria \\ E-mails: vincentuguma@gmail.com, obyobiekezie@yahoo.com
}

\begin{abstract}
Students' performance in English Language has continued to be poor despite increased exposure to the language through both print and electronic media. One of the aspects that have been blamed for this worrisome phenomenon is teaching methods. This study investigated the influence of simulation and dramatization methods of teaching on students' academic performance in English Language in Central Senatorial District of Cross River State, Nigeria. The sample for the study consisted of 320 students in senior secondary school II randomly selected from four schools in the study area. The design of the study was quasi-experimental. The instrument for data collection was an English Language Performance Test (ELPT). The data obtained for the study were analyzed using analysis of variance and analysis of covariance (ANOVA \& ANCOVA). The result showed that the use of both simulation and dramatization methods of teaching have significant influence on students' academic performance in English Language and that there is higher mean academic performance among students taught through dramatization than among those taught through simulation method. .Based on the findings, it was strongly recommended, among others, that teachers should endeavour to keep students alert and attentive in class through the use of simulation and dramatization teaching methods. This would enable them to benefit maximally from lessons thereby impacting positively on their academic performance.
\end{abstract}

Keywords: Simulation, Dramatization, Language, Performance, Conventional teaching method.

Aims Research Journal Reference Format:

Uguma, V.U. \& Obiekezie, E.O. (2018): Simulation and Dramatization Teaching Methods and Students' Academic Performance in English Language.. Advances in Multidisciplinary \& Scientific Research Journal. Vol. 4. No.2, Pp1-10.

\section{INTRODUCTION \& LITERATURE REVIEW}

The aim of teaching is to transfer knowledge to learners. For effective teaching and learning to take place, there is the need for the teacher to use different methods and techniques in teaching (Ezeudu \& Ezinwanne, 2013). Unfortunately poor academic achievement has been attributed to poor teaching methods used by teachers (Nbina, 2010; Angela \& Ugwuegbulam, 2011). The present teaching/ learning classroom should provide the fun, hands-on, challenge, interactive and collaborative environment needed by the new generation of students who have been exposed to the internet, computer usage, mobile phones and other sophisticated electrical/ electronic gadgets (Ezeudu \& Ezinwanne, 2013). Merely teaching students topics in the class may not be enough to achieve the desired mastery of the subject matter. Strategies that are both participatory and engaging may be necessary if students' performance in English Language must improve. Two of such strategies are simulation and dramatization.

Simulation is an innovative teaching method which is a learner-centred, activity-oriented teaching strategy. The word simulation comes from Latin word 'similis' meaning 'like', that is to act like, to resemble, to pretend to be. Thus, simulations are activities or materials that present real life situations, past events or organisations in such a way that students will learn and understand more about them (Uchegbu, 2006). According to Goldsim (2011) simulation helps to identify and understand factors which control the system and or to predict the future behaviour of the system. Simulation includes role plays, games, computer programmes that encourage students to become active participants in the classroom. Simulations are tools that facilitate learning through representation and practice in a repetitive, focused environment (Aldrich, 2004). According to Goldsim (2011) simulation helps to identify and understand factors which control the system and or to predict the future behaviour of the system. Simulation is a form of experiential learning scenario where the learner is exposed to real world experience defined by the teacher (Hertel \& Millis, 2002). This type of real world scenario represents a reality within which students interact and the teacher controls the pa rameters used to achieve the desired learning outcome. 
For instance, in a situation where students are assigned roles as buyers and sellers of some goods and asked to strike deals to exchange the goods, they are learning about market behaviour by simulating a market situation. During a simulation, the teacher acts more as a facilitator, helper, or resource person and less as an expert, or judge (Odo \& Odo, 2016). When difficult topics are simulated, it encourages higher degree of students' interest. Simulation is an educational tool where students learn through the application of theory and decision-making to a simulated real-world business scenario. The use of simulation technique in instruction at different levels has been reported to be of high motivational value by researchers (Chauham, 2007). It is acceptable at all levels of teaching because if any teaching technique succeeds in creating motivation in learners, all other problems may be drastically reduced (Chauham, 2007). The use of simulation technique where students are allowed to project themselves into new classroom roles helps to improve classroom dialogue, active participation and transfer of learning (Watson, 2006). Balleck (2006) reports that through the use of active learning in the form of simulations, students' presentations and problem-solving situations will better prepare them to understand. Judith (2002) asserts that simulation uses functional language where participants play a role of interaction which demand appropriate language behaviour such as social skills and social remarks suited to that situation.

The study by Heathfield (2005) on the use of simulation puts emphasis and reiterates that simulation ensures communication of meaning and uses integrative language in the process of learning the English Language. Rooney (2004), states that simulation motivates learners to learn. It requires learners to work in their small groups and make collective decisions. However, when teachers fail to use simulation learners' achievement is hampered. Simulation allows all the students to participate in the learning process. The study by Ulas (2008) on simulation affirms that simulation motivates learners and creates a positive attitude towards learning. Bello, Mlbi, and Bukar (2016) examined the effect of simulation techniques and lecture method on students' academic performance. The study used both simulation technique and lecture methods of teaching at the basic level of education in the teaching/learning environment. The study aimed at determining the best predictor among the two variables. Using quasi-experiment as a design for the study, a sample of ninety students was purposively sampled across the 3 levels of junior secondary classes. Instrument called basic science achievement test (BASAT) was used as a guide for testing the academic performance of basic science students across the levels both in experimental and control groups. Using t-test of independent variable, the study found simulation technique a very significant predictor of the mean performances of students taught through simulation game technique as their performance was higher and better than those taught using lecture method. It was recommended, among others, that teachers should make effective use of simulation method in lesson delivery as it shows to be more promising in enhancing students' academic performance at the basic level of education.

Javid, (2013), investigated the effectiveness of simulation in developing oral skills. The sample of the study comprised the whole population of freshmen in pharmacy. The experimental group was taught using integrated simulation activities in their English Language classes. The control group was taught without this innovation. The pre-intervention and postintervention scores as analyzed reported that the experimental group out-performed the control group in their oral communication. But the results of both groups in their listening skills quizzes did not show significant differences. The researcher suggested that teachers should use this innovative teaching technique especially in their oral communication clsses.

Dramatization is a favourable technique in aiding students to acquire and develop oral communication skills (Ulas, 2008). As a teaching technique, it is expected to be effective if it is implemented correctly and adequately. Dramatization as a teaching strategy has been used globally to practice and strengthen the role of the English Language as an international language (Albalawi, 2014). Therefore, drama is utilized to stimulate acquisition of skills and to facilitate learning. Dramatization entails transforming a book or event into a play or film which becomes exciting, and stimulates acquisition of skills by the learner (Campbell, 2008). Albalawi (2014) believes that the main aim of drama is to make sstudents able to use the target language communicatively. Drama is one of the most important methods that provide much more involvement for both teachers and students in the learning process. Drama is an effective method, and as Mattevi (2005) states, the use of drama in the language classroom allows the teacher to present the target language in an active, communicative and contextualized way. Dramatization helps the teacher address the four skills of language learning (listening, speaking, reading and writing); it favours and facilitates the study of some often neglected aspects of language such as pronunciation and body language (Albalawi, 2014). Özdemir and Çakmak (2008) state that drama enables students, at all levels of education, to develop their intellectual skills such as creativity, problem solving, communication, socialization and empathy and it gives individuals the opportunity for self-actualization, group work and sharing their responsibilities. 
Dramatization is a teaching strategy used by teachers to promote and strengthen mastery of the English Language for sustained learners' achievement. According to Comajoan (2014), teaching English Language through dramatization has benefits in listening and meaningful interaction where learners use their language resources during the teaching and learning process. In an earlier study, Heather (2011) indicates that dramatization pedagogy provides authentic communicative environment for the learner which stimulates understanding of concepts. In the same vein Stephanie (2011) indicates that dramatization is effective in motivating learners and promoting self-esteem through non-threatening environments for improved learners' achievement. The findings are in consonance with the views of Prasad (2011) who argues that teaching English Language using dramatization motivates learners to learn and provides them with a relaxing and challenging study environment. Further, the study supports the views of Barbu and Lucia (2007), who re-affirm that dramatization employs the use of role-play as an activity because learners develop a story and act in class, hence boosting oral skills for improved learners' achievement. In instances where English Language is taught without adopting dramatization as a strategy, learners' achievement remains low because of non-relaxing and unchallenging environment. In addition, Munther (2013) confirms the usefulness of role-play in learners' communicative competence and emphasizes that dramatization stimulates the learners' authentic conversation which raises learners' achievement. This helps the learners to overcome fear of emotion, linguistic errors, and social constraints (Maley \& Duff, 2005). In instances where these difficulties are not overcome, learners' achievement remains low. Therefore, dramatization relieves the learner from non-acquisition of difficult concepts and raises learners' achievement.

Dramatization as a teaching strategy has been used to promote and strengthen the role of the English Language in learners' achievement. Zyoud (2010) explains that dramatic genres such as role-play, simulation, mimicry and language games are utilized to stimulate acquisition of skills. In the view of Stephanie (2011) dramatization is significant in facilitating learning of oral skills. When dramatization is used in teaching and learning of the English Language, for example speech work, the learner acquires speaking skills which raise learners' achievement. In instances where teachers over look utilization of drama in teaching and learning of speech work, learners' achievement lowers. Prasad (2011) adds that students develop speaking skills that make them become fluent in speaking the English Language. Emphatically, Barbu and Lucia (2007) agree with the view of Stephanie (2011) and state that students develop nonlinguistic abilities such as gestures and body movement when role play is used in learning the English Language. Dramabased activities such as mime support both verbal and non-verbal communication.

Critically, in the teaching and learning process where dramatization is under-utilized, learners' achievement is low. Learners acquire oral skills when role-play is used in teaching speaking skills. Dramatization as a methodology can be effectively used to teach vocabulary and structure. Maley and Duff (2005) support the use of drama to teach structure and vocabulary, adding that drama can be used for revision and reinforcement of English Language concepts. For example, role-play can be utilized to revise an extract of a novel to prepare students for their final examinations (Goodwin, 2001). Also, Ulas (2008) asserts that concepts which are difficult to master can be dramatized for effective internalization and acquisition of skills in learning the English Language. Munther (2013) explains that drama stimulates naturally and spontaneously spoken English. Gill's (2005) investigation of the effect of drama on Asian law students' oralcommunication skill found that these dramatic activities can help improve their English Language oral communication skills and increase their confidence, motivation and spontaneity when speaking, while improving their non-verbal skills.

Dramatization involves a lot of conversation and discussion. These activities are suitable for low proficiency learners who are encouraged by their peers to participate in learning. They stimulate authentic learner-to-learner conversational interactions leading to higher learners' achievement. Drama motivates learners to speak English fluently. Dramatic genres enable the learners to illustrate real life situations which provide them with the incentive to work hard. When dramatic genres such as role-play and mime are used in the teaching and learning of English Language, students become attentive and participate actively in learning (Nkemka, 2012). According to Maley and Duff (2005), dramatization makes learning captivating and learners enthusiastically answer oral questions. Learners engage in purposeful activities where they communicate and concentrate on how to go about a task as drama provides them with a meaningful context to utilize the English Language. Dramatic activities such as role-play can be done in groups. Teachers assign students practice questions and the students provide answers related to the topic covered (Comajoan, 2014).

Studies have affirmed that when students realize the need to belong to a group, they are eager to complete a written task which is the case when English Language teachers use role-play and simulation methods in teaching speaking skills. Learners develop a sense of self-worth as they work together. Drama improves listening and oral communication skills. As a form of communication method, drama provides a scenario where students listen to spoken language and use vocabulary learnt meaningfully. When learners practice role-play, they read a short-play aloud in class while the teacher plans a short skit presentation which makes learning stimulating and meaningful (Maley \& Duff, 2005). The problem of mixed ability is reduced when dramatic activities are used. 
A study conducted by Eze (2010) on the effect of collaborative teaching method on students' achievement in English Language shows that there is a significant difference in students' achievement in English Language. Albalawi (2014) conducted a research on the effectiveness of teaching English Language using drama on the development of students' creative thinking. The sample population of the study comprises two randomly selected first year intermediate classes of an intermediate female school. One class of 24 students was the control group. The other class of 23 students was the experimental. The control group was taught using the traditional way of teaching whereas the experimental group was taught using drama. The results of data analysed revealed that there were statistically significant differences between the creative thinking of control group (those who study using the traditional method) and the creative thinking of experimental group (those who study using drama).

Nyagah, Kibui, Odundo, and Mwangi (2015) examined the effects of dramatization on learning of English Language in Meru County, Kenya. The target population of the study was 4,400 students, 45 head teachers, 720 teachers and 16 Directorate Quality Assurance Officers from the Ministry of Education, Science and Technology. Data were qualitative and quantitative in nature and were collected using questionnaire, interviews and test scores. Data were analysed using statistical package for social sciences (SPSS) software and descriptive statistics. The study established that when dramatic features were used in learning the English Language, learners' achievement improved.

\subsection{Statement of the problem}

It is quite worrisome that despite Government's intervention in education, students' performance especially in English Language is still at declining point. The performance of students in external examinations has been poor. This decline in students' performance has been attributed to so many factors which include poor teaching methods. Researches in education have shown that teaching and learning still follows predominantly the traditional method of teaching. The decline in performance by students could possibly be as a result of the ineffective teaching method employed by the teachers. Hence, there is the need to continuously search for and improve existing methods and innovations. Research findings reveal that simulation and dramatization methods have been of tremendous effect in improving students' performance. It is also unclear which of the two techniques would be more effective in influencing students' performance in English Language. However the problem of this study was the determination of the effect of simulation and dramatization methods on students' academic performance in English Language.

\subsection{Purpose of the study}

The general purpose of this study was to determine the influence of simulation and dramatization methods of teaching on students' academic performance in English Language in Central Education Zone Cross River State', Nigeria. Specifically, the study sought to:

i) examine the influence of simulation on the performance of students in English Language;

ii) determine the influence of dramatization method on the performance of students in English Language; and

iii) compare the effect in performance of students taught English Language using dramatization and simulation methods of teaching.

\subsection{Statement of hypotheses}

The following research hypotheses guided the study:

$\mathrm{H}_{\mathrm{O} 1}$ : The use of simulation method of teaching does not significantly influence the academic performance of students in English Language.

$\mathrm{Ho}_{2}$ : The use of dramatization method of teaching does not significantly influence the performance of students in English Language.

$\mathrm{H}_{\circ 3}$ : There is no significant main effect of treatment (simulation and dramatization methods) on the academic performance of students in English Language.

\section{METHODOLOGY}

This study utilized quasi-experimental design. The research area was the Central Senatorial District of Cross River State, Nigeria. The population for the study consisted of 3,417 Senior Secondary Two (SS II) students in public secondary schools in the district. The researcher adopted a multi-stage random sampling procedure. In the first stage, Central Senatorial District was purposively selected out the three senatorial districts in the state. In stage two, the district was stratified into two zones, A and B. In the third stage, two public secondary schools were randomly selected from each of the zones. The sample for the study consisted of 320 respondents randomly drawn from the study area. The instrument used for data collection was an English Language Performance Test (ELPT) developed by the researcher and validated by three experts in Educational Measurement and Evaluation. The reliability of the instrument was determined by administering the items to 30 students in another senatorial district who were not part of the sampled schools. 
The students' responses were subjected to Kudar-Richardson (KR-20) formula to determine the internal consistency. The reliability coefficient was obtained through test-retest method. It ranged between 0.72 and 0.81 . In zone A, comprising intact classes in two schools, the respondents were taught by the researcher different topics in English Language using simulation method. In zone B, also made up of intact classes in two schools, the respondents were taught by the researcher the same topics using the dramatization method. This was done for two weeks, with three lessons in each week. At the end of the period the students were subjected to the same test. Their performances were then compared.

\section{RESULTS}

\subsection{Hypotheses}

\section{Hypothesis 1}

The use of simulation method of teaching does not significantly influence academic performance of students in English Language. The independent variable in this hypothesis is the use of simulation method of teaching while the dependent variable is academic performance in English Language. Simple regression analysis was employed to test the hypothesis. The result of the analysis is presented in Table 1.

TABLE 1: Simple regression analysis of the influence of the use of simulation method of teaching on academic performance of students in English Language.

\begin{tabular}{|c|c|c|c|c|c|}
\hline $\mathrm{R}$ & R square & & Adjusted R square & & Std. Error of the estimate \\
\hline $.241^{\mathrm{a}}$ & .458 & & .055 & & 1.75760 \\
\hline & Sum of square & $\overline{D f}$ & Mean square & $F$ & Sig. \\
\hline Regression & 60.579 & 1 & 60.579 & 19.609 & .000 \\
\hline Residual & 982.421 & 318 & 3.089 & & \\
\hline Total & 1043.000 & 319 & & & \\
\hline
\end{tabular}

a. Dependent variable: Academic performance in English Language

b. Predictors (Constant): The use of simulation method of teaching.

Table 1 shows the result of the simple regression analysis of the influence of the use of simulation method of teaching on the academic performance of students in English Language. The regression model produced an adjusted $R^{2}$ of. 055 . This indicates that the use of simulation method of teaching accounted for $5.5 \%$ of the determinant of academic performance in English Language in the study area. This finding indicates that the use of simulation method of teaching is relatively high in the area of the study. The F-value of the Analysis of Variance (ANOVA) obtained from the regression table was $F=19.609$ and the significant value of .000 (or $p<.05$ ) at the degree of freedom (df) 1 and 318 . The implication of this result is that the null hypothesis is rejected and the finding drawn is that there is significant and high influence of the use of simulation method of teaching on the academic performance of students in English Language.

\section{Hypothesis 2}

The use of dramatization method of teaching does not significantly influence performance of students in English Language. The independent variable in this hypothesis is the use of dramatization method of teaching while the dependent variable is academic performance in English Language. Simple regression analysis was employed to test this hypothesis. The result of the analysis is presented in Table 2.

TABLE 2: Result of simple regression analysis of the influence of the use of dramatization method of teachings on academic performance in English Language.

\begin{tabular}{|c|c|c|c|c|c|}
\hline $\mathrm{B}$ & \multicolumn{2}{|l|}{ Bsquare } & \multicolumn{2}{|c|}{ Adiusted B square } & Std Frror of the estimate \\
\hline \multirow{2}{*}{$.218^{a}$} & .047 & & .044 & & 1.76763 \\
\hline & Sum of square & Df & Mean square & $\mathrm{F}$ & Sig. \\
\hline Regression & 49.404 & 1 & 49.404 & $15.812^{*}$ & .000 \\
\hline Residual & 993.596 & 318 & 3.125 & & \\
\hline Total & 1043.000 & 319 & & & \\
\hline
\end{tabular}

\footnotetext{
a. $\quad$ Dependent Variable: Academic performance in English Language

b. Predictors (Constant): The use of dramatization method of teaching.
} 
The result in Table 2 shows the simple regression analysis of the influence of the use of dramatization method of teaching on the academic performance of students in English Language. The regression model produced an adjusted $\mathrm{R}^{2}$ of .044. This indicates that the use of dramatization method of teaching accounted for $4.4 \%$ of the determinant of academic performance in English Language in the study area. This finding is an indication that the use of dramatization method of teaching is relatively high in the area of the study. The F-value of the Analysis of Variance (ANOVA) obtained from the regression table was $F=15.812$ and the significant value of .000 (or $p<.05$ ) at the degree of freedom (df) 1 and 318. The implication of this result is that the null hypothesis is rejected and the finding is that there is significant and high influence of the use of dramatization method of teaching on the academic performance of students in English Language.

\section{Hypothesis 3}

There is no significant main effect of treatment (simulation and dramatization methods) on the academic performance of students in English Language. To test this hypothesis the analysis of covariance with pre-test as covariate was used. The result of the analysis as presented in Tables 3 and 4 shows that students taught English Language with dramatization method had a high mean performance $(x=28.73)$ than simulation method $(x=28.03)$.

TABLE 3: Summary of descriptive data of experimental treatment on students' academic performance in English Language.

\begin{tabular}{llll}
\hline Treatment group & $\mathrm{N}$ & $\mathrm{X}$ & $\mathrm{SD}$ \\
Simulation $\left(\mathrm{E}_{1}\right)$ & 160 & 28.0250 & 1.93267 \\
\hline Dramatization (control) & 160 & 28.7250 & 1.60561 \\
Total & 320 & 28.3750 & 1.80820 \\
\hline
\end{tabular}

TABLE 4: Analysis of Covariance of influence of treatment on students' academic performance in English Language.

\begin{tabular}{|c|c|c|c|c|c|}
\hline Source & $\begin{array}{l}\text { Type III sum of } \\
\text { squares }\end{array}$ & Df & Mean Square & $F$ & Sig. \\
\hline Corrected model & $99.690(a)$ & 2 & 49.845 & 16.751 & .000 \\
\hline Intercept & 3292.758 & 1 & 3292.758 & 1106.534 & .000 \\
\hline Pretest & 60.490 & 1 & 60.490 & 20.328 & .000 \\
\hline Methods & 39.111 & 1 & 39.111 & 13.143 & .000 \\
\hline Error & 943.310 & 317 & 2.976 & & \\
\hline Total & 258688.000 & 320 & & & \\
\hline Corrected total & 1043.000 & 319 & & & \\
\hline
\end{tabular}

a R squared $=.096$ (Adjusted R Squared $=.090$ )

The result of the analysis as displayed in Table 4 reveals a high significant F-ratio of 13.143 for treatment effect. This value was found to be higher than critical 2.37 at 0.5 alpha levels with 2 and 317 degrees of freedom. The null hypothesis was rejected. The table also shows that the amount of total variance that accounted for the main effect of treatment was $9 \%$. The high variance percent experience was due to differential effect of the teaching methods adopted.

\section{DISCUSSION}

Hypothesis 1 The use of simulation method of teaching does not significantly influence the performance of students in English Language.

From Table 1, the null hypothesis was rejected in favour of the alternate hypothesis which states that the use of simulation method of teaching has a significant influence on the performance of students in English Language. The finding of this research is in agreement with Watson (2006) who posits that the use of simulation has significant influence on students' performance. It allows the students to project themselves into new classroom roles, helps to improve classroom dialogue, active participation and transfer of learning. Also, Balleck (2006), reports that the use of active learning in the form of simulations, students' presentations, and problem-solving situations prepares students for better understanding and performance.

The result of this study is in consonance with Rooney (2004), Heathfield (2005) and Ulas (2008). Heathfield's (2005) study on the use of simulation, reiterates that simulation ensures meaningful communication, using integrative language in the learning process of the English Language. Rooney (2004), states that simulation method motivates learners and provides them with opportunities to be involved in language learning. Ulas (2008) avers that simulation motivates learners and creates a positive attitude towards learning. 
From the foregoing, suffice it to state that teaching through simulation gives learners opportunities to actively participate in the lesson thereby imbuing in them the ability to express and explain the subject matter that might have been taught to them. It creates in their memories a link between what has been taught to them in class and what they might have seen but, might not have had the opportunity to partake in doing.

Hypothesis 2: The use of dramatization method of teaching does not significantly influence performance of students in English Language.

From the result in Table 2, the null hypothesis is rejected because the F-ratio value of 28 is greater than the critical valve of 4.96. It is however concluded that there is a significant difference in the performance of students taught English Language through dramatization method. The finding concurs with the view of Barbu and Lucia (2007), Prasad (2011), Stephanie (2011) and Comajaon (2014). Barbu and Lucia (2007) affirm that dramatization employs the use of role-play as an activity because learners develop a story and act in class, hence boost their oral skills for improved learners' performance. Prasad (2011) argues that teaching English Language using dramatization motivates learners to learn and provides them with a relaxing and challenging study environment. Similarly, Stephanie (2011) avers that dramatization is effective in motivating learners and promoting self-esteem through non-threatening environments for improved learners' performance. In the view of Stephanie (2011) dramatization is significant in facilitating learning oral skills.

When dramatization is used in teaching and learning of the English Language, for example speech work, the learner acquires speaking skills which raise learners' performance. Through dramatization, students develop non-linguistic abilities such as gestures and other body movements. According to Comajoan (2014), teaching the English Language through dramatization has benefits in listening and meaningful interaction where learners use their language resources during the teaching and learning process. Other findings supported by the finding of this research are those of McGuire (2003) and Eze (2010).

Dramatization tasks learners' intellect by making them predict what is likely to be the action or response of the next person. In the classroom situation, this skill enables the learners to think ahead of the teacher. This facilitates learning and culminates in good performance.

Hypothesis 3 There is no significant main effect of treatment (simulation and dramatization methods) on the academic performance students in English Language. From the result in Table 3, there is no significant difference between performance of students taught English Language using simulation and those taught using dramatization. This is attested to by the fact that the F-ratio is less than the critical value. Thus, the null hypothesis is accepted. The finding of this study is in agreement with the findings of earlier researchers. Schellin (2006), states that simulation role play and drama are important in foreign language classes. The author demonstrates a model for a teaching method in which students practise simulation, role play, and drama in combination. Haruyama's (2010) study similarly points out that simulation as a teaching method has many points in common with dramatization, as seen in aims and procedures. Thus, simulation and dramatization can be practised with almost the same procedure as they have similar effects on developing language skills.

Therefore, since the two techniques do not differ significantly, it is preferable if teachers use the two interchangeably, depending on the topic. Even though there are some differences in length, creativity, and flexibility, these can serve beneficially for learners as a rehearsal for real life, and inspire learners to acquire the target language in a comprehensive manner. Javid (2013) posits that simulation and dramatization involve a lot of conversation and discussion. These activities are suitable for low proficiency learners who are encouraged by their peers to participate in learning. When students realize the need to belong to a group, they are eager to complete a written task which is the case when English Language teachers use role-play and simulation methods in teaching speaking skills. Learners develop a sense of self-worth as they work together. When learners practice role-play, they read a short-play aloud in class while the teacher plans a short presentation which makes learning stimulating and meaningful (Maley \& Duff, 2005). The problem of mixed ability is reduced when dramatic activities are used. 


\section{CONCLUSION}

Based on the findings of this study, it was concluded that learning English Language in senior secondary schools can be made effective by the teacher employing simulation and dramatic methods as this study has found out that the two teaching methods have significant influence on the academic performance of students in English Language. Thus, the use of these methods by the teachers could generate interest in the subject and lead to good performance by students in the subject.

\section{RECOMMENDATIONS}

The following recommendations were made.

1. Teachers should effectively utilize simulation and dramatization methods in teaching since the methods keep students alert, attentive and involved in the teaching and learning of English Language.

2. Teachers should equip themselves with the knowledge in the use of a variety of methods of teaching so that as soon as they observe that the method in use does not benefit the students in the teaching process, they change to another.

3. Efforts should be made by teachers to involve and encourage learners in simulation and dramatization methods in order to help them gain maximally in the class and record high academic performance. 


\section{REFERENCES}

1. Albalawi, B. R. (2014). Effectiveness of teaching English subject using drama on the development of students' creative thinking. Journal of Research and Methods in Education. 4(6), 54-63.

2. Alclrich, C. (2004). Simulation and the future of learning. an innovative (and perhaps revolutionary) approach to e-learning. San Francisco, CA: Pfeiffer publishing.

3. Balleck, A. (2006). Teaching and learning physics with interactive video. Lincoln, USA: University of NebraskaLincoln Publishers. 1-4.

4. Barbu, R. \& Lucia (2007). Using drama techniques for teaching English.

5. Bello, S., Mlbi, M. B. \& Bukar, I.B.(2016). Effect of simulation technique and lecture method on students' academic performance in Mafoni Day Secondary School Maiduguri, Borno State, Nigeria. Journal of Education and Practice, 7 (23), 113-117.

6. Camajoan, L. (2014). Use of drama as a methodology to teach English in infant Education by teachers in Catalonia. Germany: Catalonia.

7. Campbell, M. P. (2008). The infusion of Theater Arts in the teaching of Language Arts: its impact on the academic achievement of Fifth Grade Students. Ph. D dissertation, College of Education and Human Services, Seton Hall University.

8. Chauham, J. (2007). A study of the simulation learning and retention of materials presented. Journal of Educational Research, 38(1). $47-58$.

9. Domike, G. C \& Odey, E. O. (2014). An evaluation of the major implementation problems of primary school curriculum in Cross River State, Nigeria. American Journal of Educational Research, 2 (6), 397-401.

10. Eze, U. (2010). Effect of collaborative teaching method on students' achievement in English Language in Umuahia Education Zone of Abia State. International Journal of Education Research and Development, 8 (2). 96-102.

11. Ezeudu, F. O. \& Ezinwanne, O. P. (2013). Effect of simulation on students' achievement in Senior Secondary School Chemistry in Enugu East Local Government Area of Enugu State, Nigeria. Journal of Education and Practice, 4 (19), 84-89.

12. Gill, C. (2005). Drama as a means of improving the advocacy skills of non-English-speaking-background students. The English Teacher, 25, 72-86.

13. Goldsim, A.K. (2011). Introduction to what is simulation. http://www.glodsim.com/web/introduction/simulationFebruary 8, 2017.

14. Goodwin, J. (2001). Teaching pronunciation. In M. Celcde - Murcia. Teaching English as a Second or Foreign Language ( 3 rd ed). Heinle \& Heinle.

15. Haruyama, J. (2010). Effective practice of role play and dramatization in foreign language education. Tokyo: Tokyo University of Foreign Studies.

16. Heather,S. (2011). How drama facilitates language learning. A case for using drama in the second language classroom Retrieved from: http:// heatherswenddal-myefolio.com/port folio/papers.

17. Heathfield, D. (2005). Spontaneous speaking: drama activities for confidency and fluency. Addlestone Delta Publishing.

18. Hertel, J. P. \& Millis, B. J. (2002). Using simulations to promote learning in Higher Education: An introduction, Sterling VA: Stylus.

19. Javid, C. Z. (2013). An investigation of effectiveness of simulation in developing oral skills: a case study. European Scientific Journal, 9(.32), 254-270.

20. Judith, R. (2002). Overcoming the fear of using drama as second language teaching. The internet test Journal 8 (116). Retrieved from: http://iteslj-org1Articles/Royka.

21. Maley, A. \& Duff, A. (2005). Drama techniques: a resource book of communication activities for language teachers. Cambridge: Cambridge University Press.

22. Mattevi, Y. (2005). Using drama in the classroom: the educational values of theatre in second language acquisition. Ph.D dissertation, Stony Brook University.

23. Munther, Z. (2013). Using drama activities and techniques to foster teaching English as a foreign language: a theoretical perspective. Retrieved from: http:/www.qou.edu/English/ First national conference/pffifles/muntherzyoudpdf.

24. Nbina, J.B. (2010). Effect of instruction in meta cognitive self-assessment stragegy on chemistry students' selfefficacy and achievement. Academic Arena.2 (11).1-10.

25. Nkemka, N.P. (2012). The effect of simulation method on students' achievement and retention in some concepts in Government in Senior Secondary schools in Nsukka Education Zone, Msc theisis. University of Nigeria, Nsukka.

26. Nyagah, G., Kibui, A., Paul Odundo,P. \& Mwangi, L. B. (2015). Effects of dramatization on learning of the English Language in Meru County, Kenya. Journal of Literature, Languages and Linguistics,.15, 93-100. 
27. Odo, C. R. \& Odo , A. I. (2016). Effect of simulation on students' interest in programming language in Secondary Schools in Enugu Education Zone of Nigeria. International Journal of Information and Education Technology, 6( 6), 477-480.

28. Ogunsaju, S. (2004). A guide to school effectiveness in Nigeria. Ibadan: Laville Publications.

29. Özdemir, S. M., \& Çakmak, A. (2008). The effect of drama education on prospective teachers' creativity. International Journal of Instruction, 1(1), 13-30.

30. Prasad, P. (2011). The functional aspects of communication skills (4th ed.). New Delhi: New A.S offset Press.

31. Rooney, R. (2004). Arts-based teaching and learning: A review of literature. Prepared for Washington DC: USA ARTS.

32. Schellin, K. (2006). Simulation, role play, and drama in a communicative classroom. Yamawaki Studies of Arts and Science, 44: 48-50.

33. Stephanie, C.W. (2011). Activating students' engagement through drama-based instructions. Austin: The University of Texas.

34. Uchegbu, A. (2006). Principles and practice teaching of methods. Ibadan: International Publishers.

35. Ulas, A. H. (2008). Effects of creative, educational drama activities on developing oral skills in primary school children. American Journal of Applied Science, 5(7), 876-880.

36. Watson, B. (2006). The effectiveness of using computer simulated experiments on junior high school students' understanding of the volume displacement concept. Journal of Research in Science Teaching, 24(6), 493-500.

37. West African Examinations Council (2011). Executive summary of entire results and chief examiners' report on the West African Senior School Certificate Examinations conducted in Nigeria in 2011. Retrieved from: http://www.waecheadquarterssgh.org/index.php?

38. Zyoud, M. (2010). Using drama activities and techniques to foster teaching English as a foreign language: a theoretical perspective. 